This is a post-print version of the article 'Sibgatullina G. (2017), Daniil Sysoev: Mission and Martyrdom, Islam and Christian Muslim Relations, Islam and Christian Muslim Relations 28(2): 163-182.' published by Taylor \& Francis and is available online: https://doi.org/10.1080/09596410.2017.1287484

\title{
Daniil Sysoev: Mission and Martyrdom
}

Gulnaz Sibgatullina ${ }^{1}$

Leiden University Centre for Linguistics, Leiden, the Netherlands

\begin{abstract}
Against what is perceived as a tacit agreement between Russia's "traditional" religions (Russian Orthodoxy, Islam, Judaism and Buddhism) to not engage in missionary work among each other's faith communities, Priest Daniil Sysoev (1974-2009) conducted assertive missionary work among Muslims. This paper analyzes Sysoev's confrontational discourse on Islam, and his strategies for missionary work. The most important among these strategies were his use of Islamic vernaculars for Orthodox-Christian preaching among Muslims, and his active engagement of Islamic authorities in public theological debates. I argue that with these strategies he followed the model of the Kazan Theological seminary in the $19^{\text {th }}$ century, who conducted missionary work among Muslim Tatars; and like the Kazan missionaries also Sysoev developed a focus on the Kriashens (Christian Tatars), and even played a role in the elaboration of Tatar Christian terminologies. Sysoev's assassination in 2009, in his own church in Moscow, raises many questions, including in how far he was actually aiming at becoming a martyr. While his parish continues to demand Sysoev's sanctification, the official Russian Orthodox Church has been ambiguous about Sysoev's rigorous and confrontational mission; but the sweeping political Orthodox activism of Sysoev's followers seems to converge with the ROC's aim to strengthen its position in Russia's society.
\end{abstract}

Key words: Daniil Sysoev, Russian Orthodox Church, Islam, missionary work, martyrdom

Since Kirill became Patriarch of Moscow and All Rus' in 2009, the main agenda of the Russian Orthodox Church (hereafter: ROC) has been his ideology of votserkovlenie (lit. "in-churching"). This term implies that the ROC sees "all segments of Russian society-from bikers to rock music fans, from drug addicts to political candidates - as its mission field"

\footnotetext{
${ }^{1}$ Email: gulnazsib@gmail.com
} 
(Burgess 2014). The ROC's Missionary department (Missionerskii otdel) began to project Orthodox mission among Russia's Muslim peoples as part of its "traditional" duty (Troshin 2016). This entails a gradual departure from the tacit agreement among the leaders of the four recognized religions in Russia - Orthodox Christianity, Islam, Judaism and Buddhism - not to fish in each other's ponds (cf., e.g., Richters 2012, 40; Knox 2005, 160).

The new policy seems to indicate a return to the Orthodox Christian mission of the Tsarist era: back then, mission primarily focused on 'Russification', that is, on the assimilation of the inorodtsy - the old umbrella term for non-Christian peoples of the VolgaUral region and the North Caucasus - and on preventing apostasy among social groups that had been baptized over the centuries, such as the Kriashen Tatars. Today, the ROC's Missionary Department targets Muslim immigrants from Central Asia, who through Orthodox Christian teaching are stimulated to integrate into Russian society. In result, some Kazakhs and Uzbeks did indeed turn to Orthodox Christianity. Another new target group for Orthodox missionary work are ethnic Russians (and representatives of other Slavic nations) who leave Christianity for embracing Islam. Although no clear data is available on the phenomenon of russkii islam ("Russian Islam", in the sense of the growing community of Slavic neophytes), the ROC cannot keep turning a blind eye on this phenomenon, especially since some Orthodox clergymen, like Viacheslav Polosin and Vladislav Sokhin (cf. Maksimov 2006), converted and became spokespersons of Islam. Some ethnic Russians even joined the fighters of the Islamic State. No wonder then that the Church recognizes russkii Islam as a serious challenge (Troshin 2016).

The gradual shift towards a more assertive mission is in line with the ROC's general policy to secure an active presence in Russia's public life and politics (Verkhovskii 2012; also Mitrokhin and Nuritova 2009). Today the Church not only issues clamorous antiabortion and anti-gay rhetoric but is also involved in legal cases, as seen in the cases of the Pussy Riot affair and of the blogger Ruslan Sokolovskii. ${ }^{2}$ Such public interventions were barely imaginable under Aleksii II (1929-2008), Russia's first post-Soviet patriarch, who wanted to keep the Church "separated from the state, but not from society" (Aleksii II 2003).

Yet already in Aleksii's time there were churchmen who advocated a more assertive approach. One of these was the Priest Daniil Sysoev (1974-2009), whose work will be analysed in this paper. Sysoev criticized the ROC for its inappropriately mild stand in

\footnotetext{
${ }^{2}$ The blogger could face up to five years in prison for his 2016 video that shows him playing Pokémon Go in a church in Yekaterinburg, and for criticizing the country's strict anti-blasphemy laws. The ROC spokesman Vladimir Legoida claimed that "it was the provocative nature of Sokolovsky's video [...] that led to his arrest" (Hongo 2016).
} 
interreligious relations, and he actively confronted nonbelievers and adherents of other faiths in personal and public debates. With hindsight, Sysoev appears as a trailblazer for the change of the ROC's course. This view, however, obscures the fact that Sysoev's criticism of the ROC was much more fundamental, and more encompassing than just a different stance in missionary strategies, as I will demonstrate in this paper.

A charismatic and sharp-tongued preacher, Sysoev was exceptionally productive as a writer, lecturer and blogger. He managed to convert a number of people to Orthodox Christianity, and today some of his stern followers, like Dmitrii Tsorionov, represent the ROC's ultra-conservative wing. Yet Sysoev's hardline approach also made him some serious enemies, and in 2009 he was shot down by unknown assailants. Sysoev's ambiguous personality and his provocative contribution to Muslim-Christian relations in post-Soviet Russia continues to feed disputes both in academic circles and religious communities: was he a radical Orthodox zealot or a true devotee who died as a martyr? Did he transform the Church tradition from a narrow ethnic subculture to a broader home accessible not only for russkie, but also for Muslim-born Tatars, migrants from Central Asia and even foreigners? Or, to the contrary, was he the enfant terrible of the ROC (Curanović 2012, 129), who undermined its carefully constructed image of a tolerant big brother in relation to Russia's other "traditional" religions?

In the first part of this paper I sketch Sysoev's image in the eyes of posterity, as shaped by the memoirs of the priest's family members as well as by friends and followers. They portray him as a faithful Orthodox Christian who died at the hands of a nonbeliever. This hagiographical trend I contrast by information acquired through interviews with two academics who knew him. In the second part I discuss Sysoev's ideology of "Uranopolitizm", and its relation to the official patriotic discourse of the ROC and the state. Sysoev's proselytizing among Muslims I analyze in the third part of the paper. Here I argue that Sysoev adopted to a large extent the strategies that missionaries of the Kazan Theological Seminary employed in the $19^{\text {th }}$ and early $20^{\text {th }}$ centuries for work among Russia's Muslims, in particular the use of Muslims' vernacular languages in church rituals and sermons, and the engaging of Muslim opponents in theological disputes (cf. Schimmelpenninck van der Oye 2011, Werth 2014, Johnson 2005, Geraci 2001 among others). As Sysoev appears to have pioneered a new form of a church-society interaction, in the last part of the paper I place Sysoev into the context of the growing church-state rapprochement under Patriarch Kirill. 


\section{The Making of a Saint}

Born in Moscow in 1974, Sysoev descended from a family with strong religious convictions. Reportedly, Sysoev's maternal great grandfather had been a Tatar imam who traced his genealogy back to Prophet Muhammad (Sysoeva and Kuropatov 2009). Sysoev's parents accepted baptism in 1977, in the period of "deep stagnation (zastoi), when everyone seemed to have forgotten about the Church" (Sysoeva 2012, 7). Sysoev's father, Aleksei Sysoev, eventually became a priest, and he still serves as a clergyman in the St. Peter and Paul Church in a southern district of Moscow. There he established, in 1990, the RadonezhIasenovo Orthodox classical gymnasium (Knorre 2014b).

According to family members, already as a child Daniil Sysoev was fascinated by religious rites: "Instead of children's games he had liturgies and sermons; he used to stand in the middle of the room preaching to hanging towels" (Suprycheva 2009a). In 1991 he enrolled in the Moscow Theological Seminary (Moskovskaia dukhovnaia seminariia). Sysoev's classmates remember that he was seen as a swift learner (samouchka), but also as a parvenu (vyskochka) and even a doctrinaire (nachetchik): a hot-head who refused to accept the authority of teachers and clerics (Lymarev 2012, 31).

Already in 1993 Sysoev unfolded his first missionary activities. With the Bible in hand, he preached on the streets, and started to have disputes with missionaries of what he called "false doctrines" or "sects", from Jehova's Witnesses over Protestants to Demon worshippers (Vladimirtsev 2011).

After graduating in 1995 Sysoev was ordained as a deacon, and started conducting Biblical conversations with people who fell under the influence of those "sects". These meetings took place at an official institutional setting - the Krutitsy Patriarchal Metochion (Krutitskoe Patriarshee podvor'e). Sysoev later analysed the experience gained during these conversations for his $\mathrm{PhD}$ (kandidatskaia) thesis in theology (titled "Anthropology and Analysis of the Seventh-Day Adventists and the Watchtower Society"), which he defended in 2000 at the Moscow Ecclesiastical Academy (Moskovskaia dukhovnaia akademiia) (Sysoev 2009i). A year later he started to work as a priest.

His fellow students report that already while being a seminarian, Daniil Sysoev longed for becoming a martyr. He used to say: "It is good to become a martyr or to retire to a monastery at the end of your life, so that you complete your life as one of the great hermits (podvizhniki)" (Lymarev 2012, 45). Sysoev explained his attraction to martyrdom also in his online book "Instruction for Immortals, or What to Do if You Died" (Sysoev 2009a: 14): 
"The death of a martyr washes away (smyvaet) all sins, except heresy and schism. All other sins - like lechery, murder, adultery - [can] be forgiven". By a strange coincidence Sysoev was acquainted with a priest who indeed became a martyr: in 1988, when he took part in restoration works at the Optina Monastery, he met hieromonk Vasilii (Rosliakov), one of three monks who would be murdered in 1993, for unclear reasons. ${ }^{3}$

In the night to 20 November 2009, Daniil Sysoev himself was shot dead after leading the divine service in St. Thomas' Church, a temporary wooden temple that Sysoev had constructed in Moscow (Rosbalt 2009). The investigation agencies saw a religious motive behind the murder, as Sysoev had repeatedly received death threats. Several weeks prior to his assassination Sysoev stated in his LiveJournal blog: "I have some news again. You'll laugh, but today Muslims again promised to kill me. This time on the phone. I am really tired of this. It is already the fourteenth time. [Such death threats] used to bother me, but I get used to that. Islam cannot hurt the ones who enjoy God's help. But I ask you all to pray for me" (Sysoev 2009g). ${ }^{4}$ The Russian media were initially very vague about the possible perpetrators, stating that they could come from among "radical Islamists or some sectarians, for example, pagans" (Newsru 2009). But on 25 December 2009, radical Islamists associated with the Caucasus Emirate (Imarat Kavkaz) claimed responsibility for the "liquidation of Allah's enemy Sysoev": "One of our brothers - a person who himself has never been to the Caucasus - made an oath of allegiance to Abu Usman [Dokku Umarov, the self-proclaimed leader of the Emirate], and expressed his desire to execute the damned Sysoev". Anyone "who dares to open his mouth to defame Islam and Muslims will share Sysoev's fate" (Hunafa 2009). Several months later, law enforcement officers in Makhachkala (Daghestan) killed a citizen of Kirgizstan, Beksultan Karibekov, when the latter resisted his arrest. There were allegations that it was Karibekov who killed the priest in Moscow, and that Karibekov was in contact with the well-known militant Islamist Said Buriatskii. ${ }^{5}$ Later the investigation agencies revoked this information (Interfax 2010). Some commentators even argued that Sysoev was assassinated because of a personal conflict with "representatives of construction business", over the land where he had built his church (Soldatov 2009).

The case on Sysoev's death is still not closed; and so is the debate whether he should be regarded as a modern martyr. While his followers demand Sysoev's official canonization

\footnotetext{
${ }^{3}$ Although Rosliakov and the other two monks have never been officially canonized, they are known as "Optina martyrs" (Optinskie mucheniki).

${ }^{4}$ In his LiveJournal entry Sysoev changed the Russian expression Bog ne vydast, svin'ia ne s"est (lit. if the Lord is merciful no swine will devour me), replacing the word "swine" by "Islam".

${ }^{5}$ On Buriatskii see Danis Garaev's paper in this issue.
} 
as a saint, the respective Synodic Commission (Sinodal'naia komissiia po kanonizatsii sviatykh) protracts: the secretary of the Commission argued that due to the unclear circumstances of Sysoev's murder it cannot be determined with certainty whether the latter took a conscious decision to die, which is a prerequisite for canonization (Maksimov 2011). Yet many churchmen and believers revere him as a martyr, simply for the way he lived, and for the fact that he died a violent death. After all, the Russian word for 'martyr' (muchenik) is related to muchenie (torment) and muka (torture), highlighting the 'physical' aspect of martyrdom, independent of the victim's intention. And even Patriarch Kirill, in his letter of condolence, called Sysoev "a martyr for sharing the Evangelical message (muchenik za delo Evangel'skogo Blagovestiia)" (Kirill 2009), which implies that the canonization of Sysoev can be just a matter of time (Sakharov 2014).

\section{Uranopolitizm versus Patriotism}

In his approach to religious mission Sysoev clearly dissented from the official ROC. In 1995, the Church published its "Conception for the Revival of ROC Missionary Activity" (Kontseptsiia vozrozhdeniia missionerskoi deiatel'nosti Russkoi Pravoslavnoi Tserkvi), and established a special Synodic Missionary Department (Sinodal'nyi Missionerskii Otdel). But programmatic documents on ROC missionary work remained very moderate in tone and goals: the 2007 document, entitled "The Conception of a Missionary Work of the Russian Orthodox Church" (Kontseptiia missionerskoi deiatel'nosti Russkoi Pravoslavnoi Tserkvi) urged Orthodox Christians to conduct "a mission of dialogue" and "of reconciliation", based on "missionary friendliness, openness, social responsiveness", and without getting involved "in extremist activities" (Kontseptsiia 2007). Obviously, the ROC was careful to avoid conflicts with the other big religions in Russia, and emphasized its respect for the rules of the secular state.

The assertive style of Sysoev's missionary activities clearly placed him beyond the scope of these regulations. Sysoev disagreed with the "defensive" mode of the ROC in interfaith relations, and he rejected the established consensus that discouraged active proselytism as the means to spread the word of God (Sysoev n.d.[a]). For Sysoev, a good attack was the best defense.

Sysoev's criticism of the ROC is embodied in his concept of uranopolitizm, with which he questioned the ROC's increasingly patriotic discourse in Putin's Russia. According to Sysoev, Christians are "just wanderers and aliens" in this world, because their real citizenship will only come in Heaven (Sysoev 2009f). Uranopolitizm (from Greek uranos - 
"heaven", and polis - "city") thus implies the supremacy of divine laws over terrestrial/secular legislation. Sysoev believed that the main and only kinship among people is "not blood or country of origin, but kinship in Christ" (Sysoev 2009f).

In denying any correlation between religion and ethnicity/nationality, Sysoev challenged one of the very fundamentals of Russian (russkii) identity: since the collapse of the Soviet Union, Orthodoxy has been promoted as an important component of Russianness (Knox 2005; Richters 2012). Sysoev challenged this conception by arguing that nations only result from the arrogance of "those who built the Tower [of Babel]"; a person who overemphasizes his or her ethnic background and connection with a given country "builds the same Tower, namely the Terrestrial Kingdom" (Sysoev 2009b).

By insisting that the Orthodox Christian Church must be open for all nationalities, Sysoev asserts that a firm believer must not be a patriot: one cannot be devoted to both the terrestrial motherland and God, for this would mean "serving two masters" (Sysoev 2009f). Such an idea could have many implications. If patriotism is not a religious virtue, Orthodox Christians should also not condemn persons who are accused of having betrayed their fatherland. Sysoev elaborated on this with the examples of the White Army General Anton Denikin (1872-1947) and the Soviet defector to the Nazis, General Andrei Vlasov (19011946), both of whom modern Russian historiography sees as traitors of the nation. In Sysoev's words, the Bible does not include "high treason in its list of sins": even a person who committed war crimes can be acquitted by God's mercy, and can enter Heaven, if s/he repents (Sysoev 2009c; also Sysoev 2009d).

While the official Church sees patriotism as an obligation of a believer (e.g., Steniaev 2007), Sysoev argued that these are false convictions that provoke God's anger. When in the summer of 2009 bad maintenance led to a serious accident at the hydro-power station in Khakassia, Sysoev posted in his LiveJournal: “Just like on 11 September 2001 God's anger stroke at America's arrogance, in August 2009 God also started to punish Orthodox people for their arrogance, [an arrogance] which in the contemporary mendacious language is called patriotism and nationalism" (Sysoev 2009e).

Sysoev's publications on uranopolitizm provoked criticism from various ROC officials and clergymen, but also from Andrei Kuraev, a Church intellectual operating on the liberal fringe of the ROC spectrum (Kuraev 2013; n.d.). Equally upset were representatives of the Russian Orthodox Old-Rite Church ("Old Believers") (Novozhilov and Shakhmatov 2007), the Russian Orthodox Church Outside of Russia (Russkaia Pravoslavnaia Tserkov' Zagranitsei) (Nazarov 2007) and lay people (e.g., Malinina 2010). 
Although the ROC never obstructed Sysoev's missionary activities, it also did not support him. To gain an own platform independent of the ROC, in 2003 Sysoev launched the project of establishing the "Community of the Church in the honour of Prophet Daniel". The goal was to build a stone church complex in the southern part of Moscow, with a capacity to accommodate 2000 persons. The complex was supposed to host a missionary school, to organize Bible lectures and lessons on Orthodox Christianity for migrant workers, and to offer psychological support for neophytes. This church became Sysoev's life project, as he hoped to establish his own "Opus Dei" (Egorov 2014) - a highly controversial institution based on the idea that an ordinary life is a path to sanctity (cf. Hutchinson 1999). Successful fundraising allowed Sysoev to start the project with the construction of a temporary centre for his flock, in the form of a wooden Church in the name of St. Thomas. There he regularly held public prayers for the conversion of "the stray Muslims and other heretics" (Knorre 2011).

\section{Proselytizing among Muslims}

When in the early 2000s Sysoev made uranopolitizm a central element of his discourse, he also shifted missionary activities: instead of Christian evangelical denominations Sysoev now targeted those individual Muslims whom he found less attached to their Islamic belief, and also became involved with the Kriashen Tatars, the communities of baptized Tatars who forcibly or voluntarily accepted Orthodox Christianity in the $16^{\text {th }}$ to $19^{\text {th }}$ centuries, and who found themselves in a vulnerable position between Orthodox Russians and Muslim Tatars.

According to Aleksandr Egorov (who attended Sysoev's classes when the latter still taught at his father's Orthodox gymnasium "Iasenevo"), Sysoev had considered missionary work among Muslims already in the mid-1990s; already back then he reflected upon the phenomenon of Kriashens, and about opportunities of conducting mission among Muslim Tatars (Egorov 2014). By 2003 he established contact with Christian Tatar activists in Moscow and organized a community of baptized representatives of Turkic nations from the post-Soviet area.

In a 2006 article ("Contemporary Trends in Islam: An Orthodox Christian Evaluation"), Sysoev provides a rather simplified categorization of Islamic trends and communities (Sysoev 2006). Sysoev distinguished five trends in Islam: 1) "everyday (obikhodnyi) Islam of Turkic peoples"; 2) "traditional Islam of peoples from the Caucasus"; 3) "Russian (russkii) Islam", 4) "Wahhabism", and, finally, 5) Shi'ism (Sysoev 2006). The 
paper was designed as a practical guide for other Orthodox Christian missionaries in Russia, outlining the specifics of the various groups.

Turkic people, Sysoev argued, profess a "soft Islam": they adjust a given religion to their local traditions and put a priority on the terrestrial (secular) legislation, not on divine (Sharia) law. According to the priest, this group is not easy to engage in any theological dispute, because adherents of "soft Islam" believe that "all religions are one way to the same summit", and therefore avoid confrontation. Sysoev also reflected on Tatar Jadidism (Muslim modernism) of the late $19^{\text {th }}$ and early $20^{\text {th }}$ centuries, which in his opinion grew out of Turkic "everyday Islam". He compared Jadidism with the Renovationist movement within the Orthodox Church, and saw both as a negative deviation from the fundamentals of the corresponding confessions. Moreover, Sysoev saw a strong link between Turkic Islam and the nationalism that he abhorred: today the Turkic peoples of the former USSR are driven by the idea that "being a Tatar or Uzbek means to be a Muslim", which, Sysoev argued, leads to the growing Islamization of Turkic nations. On the whole, however, Sysoev considered Tatars an easy mark for missionary work, claiming that in comparison to their coreligionists from the Caucasus, Muslims of the Volga-Ural region showed less fervour for Islam (Sysoev 2006).

Islam in the Caucasus was in Sysoev's eyes characterized by a stricter observation of Sharia laws, but also coupled with adat regulations. The latter Sysoev interprets as "the customary law that is essentially pagan". This, Sysoev continues, explains why the peoples of the Caucasus continue to practice blood feuds and other rituals contradicting Sharia. In a similar vein he explained Sufi influences, especially the cult of saints and the pilgrimage to holy places in the Caucasus. For Sysoev, such pagan elements in Islam prove that Islam is inferior to Christianity. Shiism seems to receive slightly less criticism from the priest, arguably because it has a cult of martyrs. Yet while a Christian martyr is "a witness of Christ's victory over death", a martyr in Islam is for him "simply somebody who suffered for Allah and wants to be rewarded for this" (Sysoev 2006).

But Sysoev was above all concerned by the growing number of ethnic Russians who convert to Islam. He argued that this phenomenon has its roots in the wars in Afghanistan (1979-1989) and Chechnya (1994-96/1999-2009). Today "representatives of the Chechen diaspora and Arab preachers" in Russia "seduce Christians into the Muslim community (musul'manstvo)" (Sysoev 2006). Many russkie Muslims follow the "Wahhabism" variant of Islam, which in Sysoev's eyes is "legalism" pure and simple; "Wahhabism" he described as an ideology for establishing a Terrestrial Kingdom that has nothing to do with the path towards salvation. 
Sysoev concluded that if cleverly approached, Islam's variety of forms and its lack of a unifying authority must facilitate Orthodox Christian mission. And indeed, Orthodox missionaries still employ Sysoev's classification. Although they stress their disagreement with the strategy of "excessive polemics", they agree that Orthodox missionaries should not be too "soft" when engaging Muslims (cf. Troshin 2016).

Christian activists often compare Sysoev with the missionaries from the Kazan Theological Seminary of the $19^{\text {th }}$ and early $20^{\text {th }}$ centuries (Ordynskii 2012; Vladimirtsev 2011; Troshin 2016), and he might indeed have taken his inspiration from his Tsarist-era predecessors. Although he never mentioned any direct connections with the Kazan Seminary, in his own mission Sysoev used similar strategies and identified similar target groups for his mission as the Kazan missionaries in the Volga-Urals.

The first of these strategies is the employment of native languages for missionary purposes. This feature was introduced by the well-known missionary Orientalist Nikolai Il'minskii (1822-91). Il'minskii also advocated the employment of priests from the local population for the teaching of the basic Orthodox tenets to the local populations. He developed a special Cyrillic alphabet and a new Tatar grammar for the community of the baptized (Kriashen) Tatars. The Kriashen language of Il'minskii's design was also understandable for Muslim Tatars, but relatively free of Arabic and Persian loanwords with Islamic semantics (Geraci 2001, 39; Kefeli 2011, 397-398).

The second feature of Sysoev's missionary work - the active dispute with Islamic authorities - was first advocated by the priest and scholar Efimii Malov (1835-1918), who confronted Russia's Muslims by organizing sophisticated anti-Islamic polemics (Mardanova 2016; also Geraci 2001, 90-97). Native-language teaching and theological disputes were meant to spread Christianity and to prevent the apostasy within the baptized communities of the Volga-Ural region.

Also Sysoev put a strong emphasis on work among Tatars: "myself being half Russian and half Tatar, it would be a sin not to preach among Tatars", as he used to say (Interfax 2008). He was proud of the Tatar part of his genealogy and believed that "half-bloods" (polukrovki) are notable for their vital energy (Neizvestnyi 2012). His aversion to nationalisms thus had much to do with his own mixed background, and under the umbrella of his uranopolitizm he intended to show that representatives of any ethnic group can become firm Orthodox Christians.

Accompanied by his disciples, Sysoev regularly visited the Tatar cultural centre in Moscow, which due to its "religious neutrality" was seen as a good platform for a "dialogue" 
with Muslims (Lapshina 2006). Once he even preached on Sabantui, the traditional summer festival of Bashkirs and Tatars, which was regarded as a provocation by the attending Muslims (Neizvestnyi 2012). In 2007 the priest headed a mission trip to Kriashen villages of Tatarstan; two years later he went on mission to the Tatarstani town of Zainsk (Vladimirtsev 2011).

But Sysoev was also interested in labor migrants from Central Asia, who in the late 1990s and 2000s came in huge numbers to Moscow and its suburbs; this led to the wellknown rise of anti-Muslim and anti-immigrant xenophobia in Russian society. Sysoev must have believed that the difference in religious norms was at the core of the conflict: in 2007 he planned conducting lessons about religious morality among workers, which he hoped would be facilitated by their respective employers. These lessons would have the purpose of "convincing migrants that Russia is not a territory of war"; otherwise, so Sysoev, "Islam allows a Muslim to do practically anything” (Suprycheva 2009b). However, he did not find the necessary financial support to carry out such lessons. In 2008 Sysoev organized a missionary trip to the Republic of Kirgizia, where he managed to baptize several local citizens (Stepanova 2009).

There are no verified records about their actual numbers, but some sources affirm that "during his life he [Sysoev] baptized about eighty Muslims" (Maksimov 2012, 111). In fact, these neophytes of Muslim origin became Sysoev's most devoted adherents: in his community they found the support and understanding that they, after their conversion, missed from their friends and family. They reported that many ordinary Orthodox parishes rejected neophytes, on the grounds that they had betrayed their national (Turkic-Tatar) tradition (Emel'ianov 2009).

Sysoev believed that he could draw on the experience of the Kazan Seminary to create what he saw as "a united Orthodox Christian mission for the Turkic-Ugric space". He envisaged this mission as a platform for an even more ambitious enterprise: the establishment of a "Unit of Christians in the Caucasus" (Lapshina 2006) to "solve spiritual problems" of the region.

\section{Mission in Islamic vernaculars}

In his work with Tatars and other Turkic-speakers, Sysoev emphasized the need to address them in their native language. His publishing house (Izdatel'stvo khrama proroka Daniila na Kantemirovskoi) issued books of prayers in three languages: Kriashen Tatar (Molitvoslov 2007a), Tatar (Molitvoslov 2007b) and Kyrgyz (Molitvoslov 2008), which 
correspond to the major ethnic groups Sysoev tried to reach out. These books contain "essential Christian prayers, psalms" and other ritual texts translated from Russian and Church Slavonic.

Sysoev himself made an effort to learn Kriashen, a historical variant of the Tatar language spoken in Kriashen communities in the Volga area. Since 2003, when he organized a community of Orthodox Christian Tatars in Moscow, the priest once a week held collective prayers in both Kriashen and Church Slavonic. It should be noted that in contemporary Kriashen parishes in the Volga-Ural region, the Kriashen language relates to Tatar in the same form as Church Slavonic relates to Russian: the former is reserved exclusively for liturgical purposes, whereas the latter is used as a language of (religious) communication. Sysoev's sermons were performed with Patriarch Aleksii's blessing, and made him the first priest in Moscow who held a special service in the Kriashen language (Maksimov 2012).

Members of Sysoev's community in Moscow wished to distinguish themselves from Muslim Tatars, and preferred to be identified not as "Orthodox Christian/baptized Tatars" but as "Kriashens". By adopting this ethnonym they constructed continuity with the centurieslong history and the rich cultural heritage of the Kriashen communities in the Volga-Ural region. The Kriashen spiritual mission in Tatarstan (cf. MissiaKriashen), however, rejected cooperation with Sysoev's group of “new Kriashens”, and also criticized Sysoev's Kriashen translations, which they regarded as inappropriate (Sizov 2016).

Perhaps in response to the opposition he met in Tatarstan, Sysoev gradually shifted from Kriashen to modern standard Tatar as the liturgical language in his community - that is, back to a language that has a significant Islamic lexicon. This shift was deemed necessary because the Tatar converts in his Moscow congregation complained that Kriashen was incomprehensible to them (Orthodox Tatars 2014). By adopting literary Tatar for translating Orthodox Christian sermons and prayers, Sysoev thus diverted from the translation strategies of Il'minskii. The latter sought to purify the Kriashen language from Islamic lexical items; terms of Arabic and Persian origin were replaced by Russian loanwords or dialect vocabulary.

How Sysoev and his collaborators employed terms of Arabic/Islamic origin can be demonstrated by the first sentence from the Creed (The Symbol of Faith), which starts with "I believe in God, the Father Almighty". In Tatar it begins as "I bring my faith to [...]", where the translators employ the Arabic term imān (which stands for 'faith' in Islam):

(1) Iman kiterämen ber Alla Ataga... (Molitvoslov 2007b, 7)

(I bring my faith to the only God Father...). 
The word "blessing" in the Holy Cross prayer in Tatar is rendered by bäräkät (Arab. baraka). In Tatar this term carries associations with Islamic theology, and marks a kind of continuity of spiritual presence and power (and next to "divine blessing" in an Islamic understanding, bäräkät also signifies "affluence"):

(2) Äy xoday, xalkïngï saqla häm yortïnga bäräkät bir (Molitvoslov 2007b, 17).

(Oh Lord, save your people and give blessing to your house.)

The translators also adopted the vocabulary used by Muslim Tatars to refer to the Supreme Being: in the first example above this is Alla (Arabic: Alläh, 'God'), and in the second it is xoday (Persian: khodā, 'Lord').

A similar approach can be found in the prayer book in Kyrgyz: e.g., the very word 'psalm' is translated as namaz-ïr (lit. 'a namaz-song') (Molitvoslov 2008, 10), which refers to the semantic field of $n a m \bar{a} z$ (of Persian origin, denoting an obligatory prayer in Islam). To take another example, the bowing element in Christian rituals (e.g. after reading certain Christian prayers) is explained in Kyrgyz as sezde qïluu - lit. 'to perform sajda' (e.g., Molitvoslov 2008, 7). This sajda usually stands for an act of prostration in the direction of the $\mathrm{Ka}{ }^{\mathrm{b}} \mathrm{ba}$, which is done by Muslims during the daily prayers.

Remarkably, the Kyrgyz book of prayers keeps the Russified variants of personal names, e.g., Iisus Khristos (Jesus Christ), whereas the translation in Tatar presents its Islamic variant Gaisä Mäsikh (Arabic, 'İsā Masīh, 'Jesus the Messiah').

The above-mentioned words of Arabic and Persian origin may have a weaker connotation with Islam in languages used for more than one religion (i.e., in Arabic, which is also the language of Oriental Christians); but Tatar and Kyrgyz remain predominantly associated with Islam. And it should be noted that also some Christian evangelical missions that entered the former Soviet Union space in the late 1980s use Muslim terminology in Christian texts. In general, this vernacularization of the Christian Holy Scriptures is believed to facilitate their acceptance in Muslim communities (Robert 2009, 32-34).

It is therefore perhaps not a surprise that Sysoev and his followers extensively used Tatar, Kyrgyz and Tajik translations of Christian texts that had been produced by evangelical missions, such as the New Testament in Kyrgyz published by the Gideons International (Inzhil 2005), an Uzbek version of the Gospel of Luke published by an organization called "Light of Hope" (containing translations by the Institute of Bible Translation in Stockholm; 
Umid Nuri 2006), and the New Testament in Tatar published by Jehovah's Witnesses (Inzhil 2013). These and other books used for missionary work among Muslim peoples were shown to me during my interviews with members of the Orthodox Christian Tatar community in Moscow in 2014.

Although Sysoev started his missionary activities by fighting non-Orthodox Christian denominations, he repeatedly suggested copying their strategies (e.g., Sysoev n.d. [a]). Sysoev thus relied on the experience of his adversaries. In fact, neither he himself nor members of his community had sufficient training in any of the Islamic vernaculars to produce high quality translations: the two little prayer books in Tatar and Kyrgyz, which Sysoev's team compiled for Orthodox Christians, have clear orthographic and stylistic shortcomings. And today, Sysoev's followers prefer to use books issued by the Moscow branch of the Institute of Bible Translation (cf. MissionCenter) in their mission among Muslims.

\section{Sysoev's Disputes with Muslim Authorities}

The second approach that Sysoev seems to have adopted from the Kazan Seminary was the readiness and eager to engage Muslims in public theological debates.

On 20 December 2005, the editors of the website Islam.ru organized a debate between Orthodox Christians and Muslims in the conference-hall of the prestigious Hotel Rossiya in Moscow (Radonezh 2005). Orthodox Christianity was represented by Daniil Sysoev as the main speaker, Andrei Redkozubov (at that time a student of Saint Tikhon's Orthodox University of Humanities), and the Orthodox theologian Aleksandr Lul'ka. Their opponents were headed by Ali Viacheslav Polosin (a former priest who became a public figure after his conversion to Islam in 1999). Polosin was supported by Askar Sabdin (a theologian who directs the information analysis centre "Ansar") and Iskander Iafisi (a Russian Muslim who participates in NORM, the National Organization of Russian Muslims). The topic of the discussion was "the Quran and the Bible". Those present at the event reported an uneven composition of the audience: there were more Muslims in the hall, mostly young men, while Christianity was mainly represented by elderly women. In the eyes of the public, neither of the sides gained a convincing victory (e.g. Vudit 2005; RusIvan 2005).

A second round of the debate was organized on 3 February 2006, and dealt with the image of God in Christianity and Islam. This time Sysoev was seconded by Georgii (Iurii) Maksimov (editor of the "Orthodoxy and Islam" web-site, and lecturer at the Moscow Theological Seminary) and ROC archpriest Oleg Steniaev. On the Muslim side the major 
figure was still Polosin, but Iafisi was replaced by Polosin's collaborator Aidyn Ali-Zade, a senior researcher of the Academy of Sciences of Azerbaijan.

Both debates were covered by the national mass media, and various communities responded to the event. The religious-patriotic Union of Orthodox Citizens (Soiuz pravoslavnykh grazhdan) argued that such kind of discussions threaten the country's stability. Speakers of this organization also challenged the legitimacy of the debaters. In their view, the participants had no right to speak on behalf of Orthodox Christianity, or of the Muslim tradition: rather, they were from "purely marginal circles who are interested in conflict" (Interfax 2005). This view was shared by the Union of Muslim Journalists (Soiuz musul'manskikh zhurnalistov) of the Russian Council of Muftis (the umbrella organization of the Spiritual Administration of the Russian Federation in Moscow): in their view, the public religious disputes lacked mutual respect, as each side was only preoccupied with detecting hostile meanings in the statements of the other. The speakers did not find a common language, and therefore did not foster dialog between the religions (Sova 2005).

A third round, envisaged to center on "Muhammad and Christ", did not take place. The two sides blamed each other for the failure. Sysoev stated he was ready to engage with the best brains in Islamic theology, and suggested the popular Islamic writer Shamil Aliautdinov (imam of Moscow's Memorial Mosque on Poklonnaia Hill) as his most authoritative sparring partner (Sysoev n.d. [b]). Yet at a later point Sysoev argued that further disputes with Muslims were pointless as long as his opponents would not be ready to question the essence of Muhammad's divine ministry (poslannichestvo). He did not regret the first two debates though, because they offered "a unique chance to preach Christ to Muslims", in front of "a hostile audience" (Sysoev 2009h).

In those public disputes of 2005 and 2006 Sysoev developed the anti-Islamic critique that would guide his subsequent lectures and publications on Russia's Muslims. He focused on the image of Allah in Islam, the personality of Prophet Muhammad, and the nature of the Quran. Sysoev also challenged the main pillars of Islam, the concept of belief in angels and djinns, and specific regulations of Sharia law.

Eventually, Sysoev rejected the idea that Muslims and Christians, as adherents of Abrahamic religions, share the same concept of God; he referred to the Council of Constantinople (1180) which laid down that Christianity's God is not the same as Allah (Sysoev 2011a). For describing the Almighty in Christianity, Sysoev used terms such as Bog (God), Tvorets (Creator), Gospod' (Lord), Otets (Father), which all denote the various characteristics or actions of God; for him, God "is Love". But for the god of Islam he only 
has Allah (of Muslims), who is "tyrannical, iniquitous, non-omniscient, artful, nonpermanent" (Sysoev 2011b, 77), and cruel. ${ }^{6}$ As the true (istinnyi) God is only in Christianity, Muslims are called upon to "come under His shroud (pokrov)" (Disput 2006, 44:10-44:20). In his later works and speeches Sysoev argued that Muslims themselves have little knowledge about their belief (Sysoev 2011a, 15), and therefore did not recognize that Allah was simply "a parody of the true God" (Sysoev 2011b, 77). Allah is a creature of Muhammad's mind, who "simply misinterpreted narrations from the Old and New Testaments" (Sysoev 2011a, 17).

In order to prove that Muhammad's claim was not credible, Sysoev referred to the places in the Bible where criteria of false prophesy are listed, and held that "Muhammad was not just a fraud (zhulik), but a man who entered sviaz' (connection), yet not with God but with Satan" (Film 2008, 39:06-39:09). Sysoev also rejected the assumption that Muhammad was simply suffering from epilepsy, as some Western Orientalists had suggested; in his view, there are clear indications that Muhammad was possessed by demons (Sysoev 2011a, 78).

As the Quran was dictated by Satan himself, Muslims "have to fight with fire, terror and executions to maintain their delusion”. From Sysoev's standpoint, the Quran not only fails to reach the highest degree of virtue (embodied in the Bible), but its "moral level is even lower than what is regarded as decency in Europe", that is, among the Westerners "who lost their piety" (Sysoev n.d.[c]).

To stress the difference Sysoev also uses different terms for elements and figures that are shared by Islam and Christianity. Thus in his writings the angel Jibril (in his spelling, Dzhabrail), in the Arabic form, is not the same as Gabriel but opposed to him; and 'Isa in the Quran cannot be Jesus, because, according to Sysoev, Muslims do not believe in his crucifixion. The only figure for whom Sysoev uses a common term is Satan: the Russian form satana (or drevnii vrag, "ancient enemy") occurs interchangeably with the Arabic/Quranic Iblis. Obviously, there is only one Satan - and it was him who formulated the Quran in which he himself figures.

In the debates Sysoev was very careful with regard to Arabic-Islamic terminology. In his own statements he himself did not bring up Arabic terms, obviously to avoid that this would provide his opponents with ammunition. Only when a specific notion was already introduced by the other side, Sysoev followed in using it, but already with his own

\footnotetext{
${ }^{6}$ His references to the Quran were based on Ignatii Krachkovskii's popular Russian Quran translation, edited posthumously in 1963; as this work is largely regarded as an unfinished work, and as a scholarly paraphrase, this choice can be questioned.
} 
interpretation. Thus when his opponents started using the Arabic term shirk (in the sense of "the sin of practising idolatry or polytheism"), Sysoev used the term but defined it as "flagrant, unforgivable sin" (Disput 2006, 42:30-42:36): Muslims do shirk when they attribute Satan's qualities to the Creator.

In his online lectures, sermons and public discussions Sysoev referred to Islamic notions more often. Words such aya, sura, Sharia, Quran, as well as Sunnism, Sufism, and Shiism, and even murid and muadhdhin, are used without translation, in the assumption that these terms are well known to both his Christian and Muslim audiences. Also words such as Wahhabi and jihad he did not define, using them as negative catch-all terms instead of providing the range of meanings that they cover.

Sometimes Sysoev uses Islamic concepts only in Russian translations, which leads to obvious simplifications. For example, he claimed that according to the Quran, "the World is divided into the territory of peace (zemlia mira) and the territory of war (zemlia voiny)", and that the latter falls into the "territory of jihad" (zemlia dzhikhada) and "the territory of truce" (zemlia peremiriia) (Sysoev 2011a, 10). These concepts (Sysoev did not give the Arabic terms Dār al-salām, Dār al-harb, Dār al-'ahd etc.) did of course not occur in the Quran, as he claimed, but were introduced by later scholars of the Islamic legal traditions; and their definitions were much more complex. Incomplete or corrupted definitions can be detected in more cases, as for instance when Sysoev defined 'adat (customary law) as "a traditional Turkic code" (in spite of the fact that many Muslim peoples have 'adat), and "peaceful (mirnyi) jihad" as a kind of Islamic missionary work (Sysoev 2011a, 12).

These patterns show that Sysoev was acquainted with the basic Arabic-Islamic terminology, and by using it he tried to convince the audience of his own competence in Islamic theology and law. However, his expertise was limited, and he tended to give Islamic terms the meanings that he would like to see in them. To stress his familiarity with Islam and Muslims he also resorted to expressions like "I have seen/heard/read by my own eyes/ears", or "when I had another talk with a Muslim". While in public debates Sysoev consistently addressed his opponents as "Muslims", in his writings he often used labels such as nevernyi (infidel), neveruiushchii (non-believer), and inoverets (adherent of a different faith). Those who came to Islam consciously, at a mature age, he called sovrativshiesia v Islam, "those who are gone astray" by entering Islam. However, Sysoev consciously refrained from using the 
highly pejorative notion of Mahometans, a term many Church authors used to emphasize that Muslims follow the pseudo-prophecy of Muhammad (Sysoev 2011b, 180). ${ }^{7}$

Obviously, Sysoev's works on Islam introduced a range of Arabic-Muslim terminology into the Orthodox religiolect, that is, the variety of the Russian language that is used by the Christian Orthodox religious community (cf. Bugaeva 2009). Also, Sysoev shaped the religious polemics with Muslims: Sysoev's videos and publications inspired many Orthodox missionaries, who now use similar strategies in their own disputes with Muslims (cf. Steniaev 2012; Morozov 2013).

While Sysoev thus seems to have followed the example of the Kazan Theological Seminary, there is one aspect in which he clearly departed from their model. When engaging Muslims in controversies on the Holy Scriptures, the Kazan theologian Efim Malov did not deny the divine nature of the Quran, but argued that Muslims just misunderstood their own Holy Scripture; in his opinion, the Quran does not contradict the teaching of Christianity (Mardanova 2016, 80). Sysoev, however, rejected the authenticity of the Quran and of Muhammad's teachings, and attacked Muhammad as a person without morality; he thereby followed the medieval tradition of anti-Islamic polemics.

The mission among Muslims brought Sysoev much public attention. Especially controversial was his booklet Marriage to a Muslim, first published in 2007 (cf. Sysoev 2011b), in which he addressed Christian women who married Muslim men (or are tempted to do so), and admonished them to stay true to their faith. Mufti Nafigulla Ashirov, chairman of the Muslim Spiritual Administration of the Asiatic Part of Russia and co-chairman of the Council of Russia's Muftis, accused the priest of extremism, and the Tatar Muslim journalist Khalida Khamidullina even filed a lawsuit against Sysoev (Islamnews 2008). Yet no litigation was conducted. The Central Muslim Spiritual Board in Ufa (in competition with the Council of Muftis, and considered to be closer to the ROC and the government at that time) preferred to ignore the priest's work altogether (Knorre 2008). Sysoev's standpoint did not meet any official criticism from the side of the ROC or the state, although it was against their rhetoric of harmony between Russia's "traditional religions".

Sysoev did not soften his polemical style, and did not shy away from comparing Islam with diseases. In his eyes, the interfaith dialog in Russia meant nothing less than the

\footnotetext{
${ }^{7}$ To be sure, in one chapter in Sysoev's Marriage to a Muslim (Sysoev 2011b) the term "Mahometans" occurs quite often, but the style of this chapter suggests that it was not written by Sysoev himself. This chapter differs from the rest of Sysoev's book by its abundance of composite sentences, elevated style, and the absence of imperatives; also, the reader is addressed in the second person plural, which is more formal than the singular form that Sysoev used to employ. Some parts of Sysoev's published works might have been authored by his companion Georgii (Iurii) Maksimov, who often wrote on similar topics (cf. Maksimov 2004, 2007, n.d.)
} 
"capitulation" of the ROC (Sysoev 2007, 0:48-0:50); the Muslims were seducing Christians to their faith "under a mask of spiritual AIDS" (Sysoev 2007, 1:13-1:24). Patience and tolerance he regarded as manifestations of spiritual sickness, and as features of persons who have no aspiration to cognize the Truth (Sysoev 2009h). The government disregarded the "real Islam", which was, in his opinion, "an inherently aggressive religion that is loaded by the bomb of jihad" (Sysoev 2009h).

\section{Conclusion: Sysoev within the Framework of a New Church Strategy}

Sysoev was killed in 2009, the year when Kirill became head of the ROC. The new patriarch made the ROC more visible in public, and drew it closer to the state. In contrast to his predecessor Aleksii II, Kirill supports the idea that the church is under siege, or under attack, and he gives more freedom to initiatives from a laity that is eager to defend its religion against "an enemy from without" (vneshnii vrag) (Knorre 2014a, 80), an imagery that fully conforms to the political course of the government. When the state leadership was in need of social and electoral support (in the wake of the parliamentary elections 2011, and the presidential elections in 2012), the ROC became a convenient mobilization force; being "a true believer" merged with "being a patriot". Kirill gave ROC activists the room to present the Church as an active institution that is able to protect itself against criticism (Knorre 2014a, 85; 2012).

This new course also leads to a re-positioning of the ROC towards Daniil Sysoev's heritage. While Sysoev had limited to no support from the official ROC during his lifetime, today he appears as a trailblazer for initiatives from below. Most of Sysoev's ardent supporters and followers - often called "Sysoevians" (Sysoevtsy), although they reject this attribution ${ }^{8}$ - graduated from the "School of the Orthodox Missionary" (Shkola pravoslavnogo missionera) that Sysoev had established in 2008. These disciples continue the priest's activities in defending and spreading Orthodox Christianity: they engage in street preaching, publish the Gospels and produce religious pamphlets in Tatar, Uzbek, Kazakh, Tajik and other languages.

The most visible personality from among this circle is Dmitrii Tsorionov (known as Enteo, b. 1989), who adopted Sysoev's ideas, strategies, and aggressive attitude towards nonOrthodox believers. Reportedly, Tsorionov also announced his readiness (and willingness?) to die in the name of Christ (Tsorionov 2014). Although the Orthodox clergy officially

\footnotetext{
${ }^{8}$ Those who continue Sysoev's activities claim that the name "Sysoevians" is a token of disrespect towards their founding father (cf. Sysoevtsy n.d.)
} 
condemned Tsorionov's attacks on Muslim migrants in 2013-2014 (which at times included physical assaults), he is believed to enjoy support from within the ROC (Solodovnik 2013). Other students of Sysoev seem to have taken a less aggressive stance; and Sysoev's closest disciples Iurii Maksimov, Oleg Steniaev and Aleksandr Lul'ka have scaled down their missionary work among Muslims after Sysoev's death.

At the same time Sysoev's arsenal of strategies to reach out to various target audiences inspired Orthodox believers to conduct more active missionary work: today there are numerous branches of his followers throughout the country. Sysoev's attempt to mobilize the laity for missionary work apparently coincides with the new program of the Church under Patriarch Kirill, and Sysoev's "School of the Orthodox Missionary" was in 2010 officially included into the structure of Synodic Missionary Department. Aleksandr Lul'ka claims that this inclusion has embedded Sysoev's methods within the official curriculum of the Belgorod Orthodox Theological Seminary that has a strong emphasis on missionary training (Kirillova 2011). This is remarkable, because Sysoev has adopted Protestant mission models and effectively adapted them for Orthodox Christian proselytism, despite the enmity of the ROC towards evangelical denominations. The priest's books are nevertheless still occupying whole shelves in Orthodox bookstores, and are regularly republished with the blessing of the ROC leadership, including the Patriarch himself.

At the same time the ROC is hesitant to give in to calls for Sysoev's canonization. To declare him a saint, or to officially acknowledge him as a model, would mean to completely change the ROC's stance towards Russia's other big religions, and to develop a missionary concept that would resemble those of the Protestant churches. The Sysoev groups still have a monopoly on missionary „shock therapy”, and its results remain highly questionable.

\section{References 9}

Aleksii II. 2003. "Rech' Sviateishego Patriarkha Moskovskogo i vseia Rusi Aleksiia II". Sedmitsa.ru, 20 November 2003: http://www.sedmitza.ru/text/445752.html

Bugaeva, Irina. 2009. "Pravoslavnyi sotsiolekt: Grammaticheskie osobennosti sovremennykh tekstov religioznoi sfery”. Izvestiia Volgogradskogo gos. ped. universiteta, Seria filol. nauki, 2 (36): 80-85

Burgess, John. 2014. "In-Churching Russia: Journeying Through the Efforts of Orthodoxy to Return Russia to Faith". First Things, May 2014: https://www.firstthings.com/article/2014/05/in-churching-russia

\footnotetext{
${ }^{9}$ Unless otherwise noted, all electronic references were still available on 21 November 2016.
} 
Curanović, Alicja. 2012. The Religious Factor in Russia's Foreign Policy: Keeping God on Our Side. London and New York: Routledge.

Disput. 2006. "Predstavlenie o Boge v Khristianstve i Islame". The dispute between representatives of Orthodox Christianity and Islam, 3 February 2006, Moscow: https://www.youtube.com/watch?v=5HipsWFuyxQ

Egorov, Aleksandr. 2014. Skype-interview with Aleksandr Egorov, associate professor at National Research University Higher School of Economics. Conducted in Leiden, 27 September 2014.

Emel'ianov, Valreii. 2009. "Reportazh: Napravlennost' pravoslavnoi missii - islam”. PortalCredo.ru, 5 January 2009: http://www.portal-credo.ru/site/?act=news\&id=39419

Film. 2008. "Fil'm-lektsia sviashchennika Daniila Sysoeva na temu: Pravoslavie i Musul'manstvo". Studia "Obitel"” Troitse Sergievoi Lavry: https://www.youtube.com/watch?v=LUwOVOmZAsU

Geraci, Robert. 2001. Window on the East: national and imperial identities in late tsarist Russia. London: Cornell University Press.

Hongo, Hadson. 2016. "Russian Blogger Charged With 'Inciting Hatred' After Playing Pokémon Go in Church". Gizmodo, 4 September 2016: http:/gizmodo.com/russianblogger-charged-with-inciting-hatred-after-play-1786177309

Hunafa. 2009. "Likvidatsiia vraga Allakha Sysoeva". Hunafa, 25 December 2009: http://hunafa.com/?p=2522.

Hutchinson, Robert. 1999. Their Kingdom Come: Inside the Secret World of Opus Dei. London: Thomas Dunne Books.

Interfax. 2005. "Zaiavlenie Soiuza pravoslavnykh grazhdan v sviazi s obostreniem polemiki po voprosam pravoslavno-musul'manskogo dialoga". Interfax-religia, 23 December 2005: http://www.interfax-religion.ru/islam/?act=documents\&div=302

Interfax. 2008. "Sviashchennik Daniil Sysoev zaiavliaet, chto v ego adres postupaiut ugrozy fizicheskoi raspravy". Interfax-religia, 19 February 2008: http://www.interfaxreligion.ru/?act $=$ news\&div $=22955$

Interfax. 2010. "Ubiitsa ottsa Daniila Sysoeva mog vkhodit' v bandu Saida Buriatskogo". Interfax, $\quad 16 \quad$ March 2010: russia.ru/South/main.asp?id=131347\&p=20

Inzhil. 2005. Inzhil/ Zabur. The Gideons International. Nashville.

Inzhil. 2013. Injil. Yanga dönya tärjemäse. Selters/Taunus: Wachtturm-Gesellschaft.

Islamnews. 2008. "Zaiavlenie protiv iereia RPTS MP”. Islamnews, 29 January 2008: http://www.islamnews.ru/news-9428.html

Johnson, Michael W. 2005. "Imperial Commission or Orthodox Mission: Nikolai Il'minskii's Work among the Tatars of Kazan, 1862-1891", Phd diss., University of Illinois at Chicago.

Kefeli, Agnès. 2011. "The Tale of Joseph and Zulaykha on the Volga Frontier: The Struggle for Gender, Religious, and National Identity in Imperial and Postrevolutionary Russia”. Slavic Review, 70(2): 373-398

Kirill. 2009. "Patriarshee soboleznovanie v sviazi s gibel'iu sviashchennika Daniila Sysoeva". 20 November 2009: http://www.patriarchia.ru/db/text/940065.html 
Kirillova, Kseniia. 2011. "Missionerskaia shkola ottsa Daniila Sysoeva priobrela status fakul'teta Belgorodskoi dukhovnoi seminarii". Pravmir.ru, 14 February 2011: http://www.pravmir.ru/missionerskaya-shkola-otca-daniila-sysoeva-priobrela-statusfakulteta-belgorodskoj-duxovnoj-seminarii/

Knorre, Boris. 2008. "Sviashchennik Daniil Sysoev i pravoslavnaia missiia sredi rossiiskikh musul'man”. Religia i pravo 44 (1): 10-13.

Knorre, Boris. 2011. "Tragediia odnogo missionera, non-konformista i gumanista kak indikator rasstanovki radikalistskikh sil v Rossii". In Religia i rossiiskoe mnogoobrazie, edited by S. Filatov, 424-442. Moscow-Saint Petersburg: Letnii sad.

Knorre, B. 2012. "Sotsial'noie sluzheniie sovremennoi Russkoi pravoslavnoi tserkvi kak otrazheniie povedencheskikh stereotipov tserkovnogo sotsiuma". In Pravoslavnaia tserkov' pri novom patriarkhe, edited by Malashenko A. and S. Filatov, 69-120. Moscow: ROSSPEN

Knorre, Boris. 2014a. "Rossiiskoe pravoslavie. Postsekuliarnaia institutsionalizatsiia v prostranstve vlasti, politiki i prava". In Montazh i demontazh sekuliarnogo mira, edited by A. Malashenko, S.Filatov, 41-102. Moscow: ROSSPEN.

Knorre, Boris. 2014b. Interview with Boris Knorre, associate professor at National Research University Higher School of Economics. Conducted in Moscow, 20 October 2014.

Knox, Zoe. 2005. Russian Society and the Orthodox Church: Religion in Russia After Communism. London and New York: Routledge Curzon.

Kontseptsiia. 2007. Kontseptsiia missionerskoi deiatel'nosti Russkoi Pravoslavnoi Tserkvi: http://www.patriarchia.ru/db/text/220922.html

Kuraev, Andrei. 2013a. "Diakon Andrei Kuraev o napadkakh ottsa Daniila Sysoeva na Osipova A.I.”. Kuraev's lecture at St Alexander Nevsky Russian School Homebush (Australia), 20 July 2013: https://www.youtube.com/watch?v=ghMNkLYZsC8;

Kuraev, Andrei. No date of publication. "O Daniile Sysoeve": https://www.youtube.com/watch?v=IEl2GLFaM6k

Lapshina, Larisa. 2006. "Pravoslavnye tatary proveli konferentsiiu v Moskve". BlagovestInfo, 11 January 2006: http://www.blagovest-info.ru/index.php?ss=2\&s=4\&id=3768

Lymarev, Aleksei. 2012. “Zhizn' za Khrista”. In Obrativshii mnogikh k pravde.., 25 - 47. Moscow: Prikhod khrama proroka Daniila na Kantemirovskoi, "Tri Sestry".

Maksimov, Iurii. 2004. Religiia Kresta i religiia Polumesiatsa. Moscow: Izdatel'stvo Moskovskogo podvor'ia Sviato-Troitskoi Sergievoi lavry.

Maksimov, Iurii. 2006. "Anatomiia izmeny". Pravoslavie. Ru, 21 August 2006: http://www.pravoslavie.ru/put/060821104600.htm.

Maksimov, Iurii. 2007. "Pochemu khristiane ne schitaiut Mukhammeda prorokom. Chast' 1". Azbuka very: http://azbyka.ru/religii/islam/muhhamad/maksimov_muhhamad-all.shtml

Maksimov, Iurii. 2012. "Siiat' kak zvezda". In Obrativshii mnogikh k pravde..., 102 - 133. Moscow: Prikhod khrama proroka Daniila na Kantemirovskoi, "Tri Sestry".

Maksimov, Iurii. No date of publication. "Sviashchennoie Pisanie: Koran ili Bibliia?". Azbuka very: http://azbyka.ru/otechnik/Georgij_Maksimov/pravoslavie-i-islam/6

Maksimov, Maksim. 2011. "Ubity, no ne proslavleny". Neskuchnyi sad, 8 February 2011: http://www.religare.ru/2 83226.html 
Malinina, Alevtina. 2010. "Kto na samom dele vedet sebia ne po-liudski". Inform-religia, 22 January 2010: http://www.inform-relig.ru/290110/analitika/220110 sysoev.html

Mardanova, Dinara. 2016. "Polemika mezhdu musul'manami i khristianami v Povolzh'e d poslednei treti XIX veka". Master thesis, European University at St Petersburg.

MissiaKriahsen. No date of publication. The official website of the Kriashen spiritual mission in the republic of Tatarstan: http://missiakryashen.ru/

MissionCenter. No date of publication. Missionerskii tsentr im. iiereya Daniila Sysoeva (the official website of the Mission Center named after Daniil Sysoev) http://missioncenter.com/gastrobaiters

Mitrokhin, Niklolai, and Aziza Nuritova. 2009. "The Russian Orthodox Church in Contemporary Russia: Structural Problems and Contradictory Relations with the Government, 2000-2008”. Social Research 76 (1): 289-320.

Molitvoslov. 2007a. Pravoslavnyi molitvoslov na kriashenskom iazyke. Moscow: Izdatel'stvo khrama Proroka Daniila na Kantemirovskoi.

Molitvoslov. 2007b. Pravoslavnyi molitvoslov na tatarskom iazyke. Moscow: Izdatel'stvo khrama Proroka Daniila na Kantemirovskoi.

Molitvoslov. 2008. Pravoslavnyi molitvoslov na kyrgyzskom iazyke. Moscow: Izdatel'stvo khrama Proroka Daniila na Kantemirovskoi.

Morozov, Konstantin. 2013. "Dialog mezhdu pravoslavnymi i musul'manami. 1-aia peredacha". 23 May 2013: https://www.youtube.com/watch?v=1WA2wKFSqYs

Nazarov, Mikhail. 2006. "Otvet ottsu Daniilu Sysoevu na ego stat'iu “Zarubezhnaia tserkov': raskol ili eres'?". Izdatel'stvo "Russkaia Ideia”, 26 December 2006: http://www.rusidea.org/?a=12034.

Neizvestnyi. 2012. Neizvestnyi Daniil. Vospominania o sviashennike Daniile Sysoeve. Moscow: Blagotvoritel'nyi fond "Missionerskii tsentr imeni iereia Daniila Sysoeva". Ebook: http://mission-center.com/publicatsii/11161-daniil-book

Newsru. 2009. "Moskovskogo sviashchennika Daniila Sysoeva zastrelili po religioznym motivam, priznaiet SKP”. NewsRu, 20 November 2009: http://www.newsru.com/religy/20nov2009/sysoyev.html

Novozhilov, Valentin and Pavel Shakhmatov. 2007. "Protoierei Valentin Novozhilov i Pavel Shakhmatov vs o. Daniil Sysoev". Sovremennoe drevlepravoslavie, 12 October 2007: https://staroobrad.ru/modules.php?name $=$ News2\&file=print\&sid $=220$

Ordynskii, Vasilii. 2012. “Kazan' reabilitiruet imia velikogo prosvetitelia”. Russkaia narodnaia liniia, 7 June 2012: http://ruskline.ru/analitika/2012/06/07/kazan_reabilitiruet_imya_velikogo_prosvetitelya 1

Orthodox Tatars. 2014. Interviews with members of the Orthodox Tatar community in Moscow. Conducted in St. Thomas' Church in Moscow, 23-24 October 2014.

Radonezh. 2005. "Sostoialsia pervyi v Rossii publichnyi disput musul'man i pravoslavnykh". Radonezh, 21 December 2005: http://radonezh.ru/news/sostoyalsya-pervy-v-rossiipublichny-disput-musulman-i-pravoslavnykh-17196.html

Richters, Katja. 2012. The Post-Soviet Russian Orthodox Church: Politics, Culture and Greater Russia. London: Routledge. 
Robert, Dana L. 2009. Christian Mission: How Christianity Became a World Religion. Chichester: Wiley-Blackwell.

Rosbalt. 2009. "Otvetstvennost' za ubiistvo Daniila Sysoeva vziali islamisty". Rosbalt, 26 December 2009: http://www.rosbalt.ru/moscow/2009/12/26/700646.html

RusIvan. 2005. "Teologicheskoe: po sledam sostoiavshikhsia religioznykh debatov pravoslavnykh i musul'man". LiveJournal, 17 December 2005: http://lj.rossia.org/users/pyc ivan/163821.html

Sakharov, Kirill. 2014. "Kanonizatsiia sviashennika Daniila Sysoeva - delo vremeni". Russkaia narodnaia liniia, 26 November, 2014: http://ruskline.ru/special_opinion/2014/11/kanonizaciya_svyawennika_daniila_sysoeva delo vremeni/

Schimmelpenninck van der Oye, David. 2011. "Know Thine Enemy: The Travails of the Kazan School of Russian Missionary Orientology". In Religion and Identity in Russia and the Soviet Union: A Festschrift for Paul Bushkovitch, edited by N. Chrissidis, C. Potter and J. Spock, 145-164. Columbus: Slavica.

Sizov, Dmitrii. 2016. Interview with priest Dmitrii Sizov, member of the Kriashen spiritual mission in the republic of Tatarstan. Conducted in Kriash-Sreda, 19 July 2016.

Soldatov, Aleksandr. 2009. "Uranopolit stal muchenikom”. Novaia Gazeta, 25 November 2009: http://www.novayagazeta.ru/society/42531.html

Solodovnik, Svetlana. 2013. "Rossiia: ofitsial'naia tserkov' vybiraet vlast"”. Pro et contra, 34 (59): 6-26.

Sova. 2005. "SPG bespokoit sostoianiie mezhreligioznogo dialoga v Rossii". Tsentr SOVA, 23 December 2005: http://www.sova-center.ru/religion/news/interfaith/christianislam/2005/12/d6843/

Steniaev, Oleg. 2007. "Khristianstvo i patriotism". Pravoslavie.ru, 14 June 2007: http://www.pravoslavie.ru/94102.html

Steniaev, Oleg. 2012. "Kak mozhno nachat' dialog s musul'manami”. The Youth festival "Odigitria", Vitebsk: https://www.youtube.com/watch?v=gr2c hYTY4I

Stepanova, Ekaterina. 2009. "Pamiati ottsa Daniila Sysoeva". Pravmir.ru, 20 November 2009: http://www.pravmir.ru/po-sledam-apostola-fomy-missionery-v-kirgizii/

Suprycheva, Evgenia. 2009b. "Batyushku ubili za propovedi sredi musul'man?". Komsomol'skaia Pravda, 20 November 2009: http://www.kp.ru/daily/24397/574542/

Suprycheva, Evgeniia. 2009a. "Mat' ubitogo sviashchennika Daniila Sysoeva: 'On gotovil menia k svoiei smerti!"”. Blagovest-Info, 24 November 2009: http://www.blagovestinfo.ru/index.php?ss=2\&s=7\&id=31046

Sysoev, Daniil. 2006. "Sovremennyie techeniia islama - pravoslavnaia otsenka". Imperskoe vozrozhdenie (1), 2006: http://fondiv.ru/articles/1/57/

Sysoev, Daniil. 2007. "On Tolerance". Speech on the presentation of his "Marriage to a Muslim" book: http://vk.com/video76284242_167821607

Sysoev, Daniil. 2009a. Instruktsiia dlia bessmertnikh ili chto delat', esli Vy vse-taki umerli. Moscow: Blagovest. E-book: http://www.etextlib.ru/Book/Details/15700

Sysoev, Daniil. 2009b. "Otvet Dmitriu Anatol'evichu (no ne Medvedevu)". LiveJournal, 18 October 2009: http://pr-daniil.livejournal.com/57596.html 
Sysoev, Daniil. 2009c. "Uranopoliticheskie kriterii otsenki istorii". LiveJournal, 7 September 2009: http://pr-daniil.livejournal.com/47465.html

Sysoev, Daniil. 2009d. "2 Mirovaya voina i chestnost"”. LiveJournal, 10 September 2009: http://pr-daniil.livejournal.com/48610.html

Sysoev, Daniil. 2009e. "A Sud to nad pravoslavnymi narodami uzhe nachalsia!". LiveJournal, 24 August 2009: http://pr-daniil.livejournal.com/45307.html

Sysoev, Daniil. 2009f. "Uranopolitizm i patriotizm”. Uranopolitizm: https://uranopolitism.wordpress.com

Sysoev, Daniil. 2009g. "Dobrye musul'mane". LiveJournal, 9 October 2009: http://prdaniil.livejournal.com/56054.html

Sysoev, Daniil. 2009h. "Skaip-konferentsiia so sviashchennikom Daniilom Sysoevym". Stavros, 15 June 2005: http://stavroskrest.ru/content/skajp-konferenciya-sosvyacshennikom-daniilom-sysoevym

Sysoev, Daniil. 2009i. "You Wish to See Many Miracles - You Should Become a Missionary or a Martyr". Sysoev's autobiography at Orthodoxy and the World, 25 November 2009: http://www.pravmir.com/article 793.html

Sysoev, Daniil. 2011a. Islam. Pravoslavnyi vzgliad. Moscow: Avtonomnaia nekommercheskaia organizatsiia "Dukhovnoe nasledie".

Sysoev, Daniil. 2011b. Brak s musul'maninom. Moscow: Avtonomnaia nekommercheskaia organizatsiia "Dukhovnoe nasledie ".

Sysoev, Daniil. No date of publication (a). "Pokhvala prozelitizmu”. Missionerskii tsentr: http://mail.mission-shop.com/index.php/ru/publicatsii/583-2009-12-30-00-52-53.html (no longer available, last accessed 19 February 2015).

Sysoev, Daniil. No date of publication (b). "Spletni o islamo-khrisitanskom dispute". Pravoslavie i islam: http://www.orthodoxy-islam.com/disput1.htm

Sysoev, Daniil. No date of publication (c). "Mozhet li Koran pretendovat' na to, chto on - eto slovo Boga". Missionerskii tsentr: http://mission-center.com/publicatsii/175-koran

Sysoeva, Anna. 2012. "Vospominaniia o detstve Daniila". In Obrativshii mnogikh $k$ pravde..., 5 - 24. Moscow: Prikhod khrama proroka Daniila na Kantemirovskoi, "Tri Sestry".

Sysoeva, Iulia, and Timofei Kuropatov. 2009. "Matushka Iuliya Sysoeva: ob ottse Daniile, shast'e, chudesakh i muchenichestve". Pravmir.ru, 17 December 2009: http://www.pravmir.ru/matushka-yuliya-sysoeva-ob-otce-daniile-schaste-chudesax-imuchenichestve/

Sysoevtsy. No date of publication. "Sysoevtsev ne syschestvuet". Missionerskii tsentr im. Iiereya Daniila Sysoeva: http://mail.mission-shop.com/publicatsii/16107-nosysoev

Troshin, Aleksii. 2016. "Pravoslavnaia khristianskaia missiia v islamskoi srede v Rossii: istoriia i sovremennost'“. Ofitsial'nyi sait Missionerskogo otdela Moskovskoi ieparkhii, 24 September 2016. http://infomissia.ru/2016/09/24/pravoslavnaya-xristianskayamissiya-v-islamskoj-srede-v-rossii-istoriya-i-sovremennost/

Tsorionov, Dmitrii. 2014. "Dmitrii Tsorionov (Enteo), lider obshchestvennogo dvizheniia "Bozh'ia Volia". Interview on Ekho Moskvy, 28 June 2014: http://www.echo.msk.ru/programs/oni/1349058-echo/

Umid Nuri. 2006. Mukaddas Khushkhabar. Umid Nuri, Bishkek: Al’ Salam. 
Verkhovskii, Aleksandr. 2012. "Ideologiia patriarkha Kirilla, metody ee prodvizheniia i ee vozmozhnoe vliianiie na samosoznanie Russkoi pravoslavnoi tserkvi”. Sova-Tsentr, 17 October 2012: http://www.sova-center.ru/religion/publications/2012/10/d25570/

Vladimirtsev, Oleg. 2011. "Nekotorye aspekty missii sredi inovertsev na primere o. Daniila Sysoeva". Russkaia narodnaia liniia, 19 November 2011: http://ruskline.ru/analitika/2011/11/19/nekotorye_aspekty_missii_sredi_inovercev_na p rimere o daniila sysoeva

Vudit. 2005. "Sysoev vs. Polosin". LiveJournal, 17 December 2005: http://lj.rossia.org/users/vudit/71650.html

Werth, Paul. 2014. The Tsar's Foreign Faiths: Toleration and the fate of Religious Freedom in Imperial Russia. Oxford: Oxford University Press. 